\title{
KARAKTERISTIK PAPAN PARTIKEL DARI LIMBAH KULIT KACANG TANAH DENGAN PEREKAT ALAMI ASAM SITRAT DENGAN PELARUT ASAP CAIR
}

\author{
Characteristics of particleboard made of peanut shell \\ with citric acid adhesive and liquid smoke solvent
}

\section{Agus Ngadianto ${ }^{1}$, Ganis Lukmandaru², Dhuria Maulidya Sari ${ }^{3}$, Utari Mardatillah ${ }^{3}$, dan Dera Farah Fitria ${ }^{3}$}

\author{
${ }^{1}$ Dosen Program Studi Pengelolaan Hutan, Sekolah Vokasi, Universitas Gadjah Mada \\ ${ }^{2}$ Dosen Program Studi IImu Kehutanan, Fakultas Kehutanan, Universitas Gadjah Mada \\ ${ }^{3}$ Mahasiswa Program Studi Pengelolaan Hutan, Sekolah Vokasi, Universitas Gadjah \\ Mada \\ Email: agus.ng@ugm.ac.id
}

\begin{abstract}
Binderlessboard is one of the potential eco-friendly products that can be developed. Utilization of natural adhesives for non-wood composite is still very limited. Therefore, this research is focused on effects of citric acid content and pressing time on characteristics of particleboard made from peanut shell including its durability to dry wood termite attacks. Peanut shell particles were used as raw materials. Citric acid dissolved in liquid smoke which functioned as a water substitute solvent under a certain ratio and the concentration of the solution was adjusted to $60 \%$. The use of liquid smoke is expected to increase the durability of the particleboard. Factors used in this research were citric acid content (10-30\% based on dry weight particles) and pressing time (10 minutes and 15 minutes). Properties of particleboard were analyzed based on Japanese Industrial Standard (JIS) A 5908 for particleboard. The dry wood termite resistance was then analyzed for its weight loss and mortality after 4 weeks. The results showed that the best particleboard was obtained from the treatment of $30 \%$ citric acid content with 15 minutes of pressing time where only the modulus of rupture and modulus of elasticity did not met the requirement of JIS A 5908 type 8 with the thickness swelling were $3.276 \%$, water absorption were $44,991 \%$, internal bonding were $4.679 \mathrm{kgf} / \mathrm{cm}^{2}$, modulus of rupture were $26.822 \mathrm{kgf} / \mathrm{cm}^{2}$, and modulus of elasticity were $8,986,058 \mathrm{kgf} / \mathrm{cm}^{2}$. The best value of weight loss and mortality of dry wood termites on particleboard was obtained in a combination of $30 \%$ citric acid content with 10 minutes pressing time were $1.083 \%$ and $38.67 \%$ respectively.
\end{abstract}

Keywords: adhesive content, citric acid, liquid smoke, peanut shell, pressing time

\begin{abstract}
Abstrak
Papan partikel tanpa perekat sintetis merupakan salah satu produk ramah lingkungan yang sangat potensial untuk dikembangkan. Penggunaan perekat alami dan bahan baku non kayu dalam pembuatan papan partikel ini masih sangat terbatas. Oleh karena itu penelitian ini difokuskan pada pengaruh kadar perekat asam sitrat dan waktu kempa terhadap karakteristik papan partikel dari kulit kacang tanah termasuk ketahanannya terhadap serangan rayap kayu kering. Partikel kulit kacang tanah digunakan sebagai bahan baku penelitian. Asam sitrat dilarutkan dalam asap cair yang difungsikan sebagai pelarut pengganti air dengan konsentrasi $60 \%$ pada komposisi tertentu.
\end{abstract}


Penggunaan asap cair diharapkan dapat menambah sifat keawetan papan partikel yang dihasilkan. Faktor pada penelitian ini adalah kadar perekat asam sitrat (10-30\% berdasarkan berat kering udara partikel) dan waktu kempa (10 menit dan 15 menit). Sifat fisika dan mekanika papan partikel diuji berdasarkan standar pengujian JIS A 5908. Pengujian ketahanan terhadap serangan rayap kayu kering juga dilakukan dengan menghitung nilai pengurangan berat dan mortalitas rayap setelah 4 minggu. Hasil penelitian menunjukkan bahwa papan partikel terbaik diperoleh dari perlakuan kadar perekat asam sitrat $30 \%$ dengan waktu kempa selama 15 menit dimana hanya nilai modulus patah dan modulus elastisitas saja yang tidak memenuhi standar JIS A 5908-2003 dengan nilai pengembangan tebal sebesar 3,276\%, penyerapan air sebesar $44,991 \%$, keteguhan rekat internal sebesar 4,679 $\mathrm{kgf} / \mathrm{cm}^{2}$, modulus patah sebesar $26,822 \mathrm{kgf} / \mathrm{cm}^{2}$, dan modulus elastisitas sebesar $8.986,058 \mathrm{kgf} / \mathrm{cm}^{2}$. Nilai pengurangan berat dan mortalitas rayap terbaik pada papan partikel diperoleh pada kombinasi perlakuan kadar perekat asam sitrat 30\% dengan waktu kempa 10 menit yaitu sebesar $1,083 \%$ dan $38,67 \%$.

Kata kunci: Asam sitrat, Asap cair, Kadar perekat, Kulit kacang tanah, Waktu kempa

\section{Pendahuluan}

Salah satu teknologi pengolahan kayu sebagai alternatif dari pemanfaatan kayu yang jumlahnya semakin terbatas adalah pembuatan produk komposit berupa papan partikel. Pada awalnya, kayu atau limbah kayu merupakan bahan utama dalam pembuatannya, namun seiring dengan perkembangan teknologi, pembuatan papan partikel ini berangsur-angsur telah bergeser menggunakan bahan berupa limbah perkebunan dan pertanian atau biomassa yang ketersediaannya melimpah. Papan partikel pada umumnya menggunakan perekat yang berbasis formaldehida, seperti urea formaldehida, fenol formaldehida, dan melamin formaldehida. Kerugian yang ditimbulkan ketika menggunakan perekat berbasis formaldehida adalah emisi formaldehida yang cukup tinggi atau melebihi standar yang sudah ditetapkan sehingga dapat merugikan kesehatan, baik dalam jangka waktu pendek maupun panjang. Oleh karena itu, inovasi pembuatan papan partikel banyak dilakukan untuk menurunkan emisi formaldehida tersebut, diantaranya dengan mengembangkan papan partikel dengan perekat non sintetik atau penggunaan bahan pengaktif alami atau dapat juga tanpa menggunakan perekat sintetik yang dikenal dengan nama binderless particleboard (Laemsak dan Okuma, 2000; Velasquez et al., 2002; Xu et al., 2003; Van Dam J.E.G et al., 2004; Widyorini et al., 2005; Okuda dan Sato, 2006; Widyorini et al., 2013).

Salah satu bahan perekat alami yang berfungsi sebagai pengaktif yang dikembangkan adalah asam sitrat (2-hydroxy-1,2,3-propanetricarboxylic acid) yang mengandung tiga gugus karboksil dan terbukti dapat digunakan sebagai agen pengikat pada produk papan partikel dari bambu (Widyorini et al., 2013). Produk papan partikel bambu tersebut memiliki kekuatan yang baik, bahkan ketahanan terhadap air semakin meningkat dengan meningkatnya kadar asam sitrat yang diberikan. Penambahan sampai $40 \%$ asam sitrat berdasarkan berat kering udara partikel bambu dengan suhu pengempaan 200 dan 220 ${ }^{\circ} \mathrm{C}$ masih memperlihatkan peningkatan kualitas secara signifikan. Umemura et al. (2011) menegaskan bahwa asam sitrat bertindak sebagai agen perekat melalui ikatan kimia dan mempunyai potensi sebagai perekat kayu alami yang ramah lingkungan. Asam sitrat juga dapat berikatan dengan baik pada gugus hidroksil dari kayu (Umemura et al., 2012). Penelitian menggunakan asam sitrat sebagai bahan perekat komposit masih relatif baru dan belum banyak dilakukan. Oleh karena itu, penelitian menggunakan asam sitrat sangat menarik untuk dilakukan karena merupakan bahan perekat yang ramah lingkungan.

Bahan baku yang digunakan pada penelitian ini adalah kulit kacang tanah (Arachis hypogaea L). Tanaman kacang tanah termasuk tanaman polong-polongan yang potensinya menduduki nomor dua setelah kedelai di Indonesia. Selama ini, kegunaan kacang tanah 
sebagian besar masih pada pengolahan bijinya saja yang kemudian diolah menjadi bermacam produk makanan. Sementara itu, kulitnya belum dimanfaatkan secara maksimal. Limbah kulit kacang tanah biasanya hanya digunakan sebagai pakan ternak saja. Di Indonesia, biomass kacang tanah yang dimanfaatkan selama ini adalah biji untuk bahan pangan, brangkasan untuk pakan ternak, dan kulit polong sebagai pakan ternak dan bahan bakar. Apabila dihitung dari produksi nasional tahun 2011 yaitu sebesar 695.977 ton polong kering, dan diasumsikan rendemen polong maksimum sebesar $40 \%$, maka rendemen brangkasan yang didapat adalah $60 \%$ atau sebesar 1.043 .965 ton. Rendemen biji terhadap polong diperkirakan sebanyak $60 \%$ sehingga rendemen kulit polong hanya $40 \%$ atau sebesar 278.390 ton (Anonim, 2015). Kandungan kimia kulit kacang tanah terdiri dari air $9,5 \%$, abu 3,6\%, protein $8,4 \%$, selulosa $63,5 \%$, lignin $13,2 \%$ dan lemak 1,8\% (Deptan, 2008). Berdasarkan kandungan kimia tersebut, diduga kulit kacang tanah mempunyai potensi sebagai bahan baku papan partikel.

Selain sifat fisika dan mekanika papan partikel, sifat keawetan papan partikel juga perlu diperhatikan agar memberikan umur pakai papan partikel yang lebih lama. Salah satu kendala papan partikel dari bahan baku berlignoselulosa adalah serangan organisme perusak kayu seperti rayap kayu kering. Walther et al. (2007) meneliti tentang intensitas serangan rayap kayu kering terhadap papan serat kenaf dengan perekat fenol formaldehida dengan hasil bahwa kandungan perekat juga sangat berpengaruh terhadap intensitas serangan rayap. Widyorini et al., (2015) melakukan penelitian tentang ketahanan papan partikel bambu dengan perekat asam sitrat dan memberikan hasil bahwa penambahan asam sitrat dapat menghasilkan papan dengan ketahanan terhadap serangan rayap kayu kering yang baik dengan nilai kisaran nilai mortalitas rayap sebesar $57-78 \%$. Selama ini, penelitian mengenai ketahanan papan partikel dengan perekat asam sitrat terhadap serangan rayap kayu kering masih terbatas. Selain itu, perlakuan penambahan bahan pengawet pada asam sitrat belum pernah dilakukan. Pada penelitian ini, perekat asam sitrat akan dikombinasikan dengan penambahan bahan pengawet alami berupa asap cair yang difungsikan sebagai pelarut pengganti air atau aquades dengan harapan dapat menambah sifat keawetan papan partikel yang dihasilkan. Asap cair merupakan bahan pengawet alami berbentuk cairan yang memiliki kandungan utama berupa fenol dan asam organik yang bersifat bakteriostatik/baktersidal. Komposisi asap cair menurut Maga (1988) adalah air 11 - $92 \%$, fenol 0,2 - 2,9\%, asam 2,8 - 4,5\%, karbonil 2,6 - 4,6\%, ter $1-17 \%$. Sementara itu, menurut Bratzlerr et al. (1969) menyatakan bahwa komponen utama kondensat asap kayu adalah karbonil $24,6 \%$, asam karboksilat $39,9 \%$ dan fenol $15,7 \%$. Oleh karena hal tersebut diatas, tujuan dari penelitian ini adalah untuk mengetahui pengaruh kadar asam sitrat dengan pelarut asap cair dan waktu kempa terhadap sifat fisika, mekanika serta ketahanan papan partikel dari kulit kacang tanah terhadap serangan rayap kayu kering.

\section{Metode}

\section{Bahan Penelitian}

Bahan yang digunakan pada penelitian ini adalah limbah kulit kacang tanah yang diperoleh dari daerah Bantul. Untuk menyeragamkan ukuran, kulit kacang tanah yang diperoleh selanjutnya dibuat partikel dengan ukuran lolos saringan 10 mesh dan tertahan saringan 60 mesh serta dikeringkan sampai mencapai kadar air kering udara. Bahan perekat yang digunakan adalah asam sitrat dan pelarut yang dipakai adalah berupa bahan pengawet cair berupa asap cair sebagai pengganti air atau aquades. Penelitian ini dilakukan pada tahun 2017 dengan memanfaatkan bahan baku kacang tanah yang kesediaannya melimpah di Kabupaten Bantul, Yogyakarta. 


\section{Prosedur Pelaksanaan}

a. Pembuatan Larutan Perekat

Pembuatan larutan perekat dilakukan dengan mencampurkan bahan terlarut berupa asam sitrat dan bahan pelarut berupa asap cair dengan perbandingan 60:40. Pencampuran dilakukan dengan cara pemanasan sampai didaptkan larutan perekat. Larutan perekat dibuat pada berbagai variasi kadar perekat asam sitrat. Selanjutnya, partikel dicampurkan dengan larutan asam sitrat lalu di oven pada suhu $80{ }^{\circ} \mathrm{C}$ selama kurang lebih 24 jam.

b. Pembuatan Papan Partikel

Partikel kulit kacang tanah yang telah dicampur larutan asam sitrat selanjutnya dibuat mat dengan ukuran $25 \mathrm{~cm} \times 25 \mathrm{~cm}$ dengan target kerapatan 0,8 $\mathrm{g} / \mathrm{cm}^{3}$ serta ketebalan $0,7 \mathrm{~cm}$. mat yang terbentuk lalu dikempa pada suhu $180{ }^{\circ} \mathrm{C}$ dengan tekanan 1.000 Psi. Variasi perlakuan yang dilakukan dalam penelitian ini adalah waktu kempa selama 10 dan 15 menit dan variasi kadar perekat asam sitrat sebanyak 10\%, 20\% dan 30\%. Untuk setiap kombinasi perlakuan dibuat tiga papan partikel sebagai ulangan.

c. Pengujian Sifat Fisika dan Mekanika

Pengujian mengacu pada prosedur pengujian Japanese Industrial Standard (JIS) A 5908 (2003) untuk papan partikel. Sifat fisika yang diuji meliputi kerapatan, pengembangan tebal dan penyerapan air setelah perendaman 24 jam pada air kondisi ruangan, sedangkan sifat mekanika meliputi keteguhan rekat internal, modulus patah dan modulus elastisitas.

d. Pengujian Papan Partikel Terhadap Serangan Rayap Kayu Kering

Pengujian terhadap serangan rayap kayu kering mengacu pada Standard JIS K 1571 (2004) dengan menggunakan sampel papan partikel ukuran $5 \mathrm{~cm} \times 5 \mathrm{~cm} \times 0,7 \mathrm{~cm}$. selanjutnya seluruh contoh uji dioven pada suhu $40{ }^{\circ} \mathrm{C}$ hingga diperoleh berat sebelum pengumpanan. Persiapan pengumpanan dilakukan dengan memasukkan 50 ekor rayap kayu kering dewasa, sehat dan aktif kedalam wadah contoh uji papan partikel selama 4 minggu. Setelah empat minggu pengamatan, contoh uji dibersihkan dari rayap-rayap dan kemudian dikeringkan kembali dalam oven pada suhu $40{ }^{\circ} \mathrm{C}$ hingga didapatkan berat sesudah pengumpanan. Perhitungan mortalitas rayap dan pengurangan berat berdasarkan persentase perjumlah total rayap dan berat kering contoh uji.

\section{Analisis Data}

Rancangan penelitian menggunakan faktorial dalam rancangan acak lengkap. Faktor pertama adalah waktu pengempaan (10 dan 15 menit), dan faktor kedua adalah kadar perekat asam sitrat (10\%, 20\% dan 30\%). Data pengamatan yang diperoleh dianalisis dengan uji $F$ (Anova). Apabila hasil uji $F$ berbeda nyata maka dilanjutkan dengan uji lanjut Tukey HSD.

\section{Hasil Dan Pembahasan}

\section{Sifat Fisika dan Mekanika Papan Partikel}

Kerapatan rata-rata papan partikel dari kulit kacng tanah dengan perekat asam sitrat dan pelarut asap cair adalah $0,74 \mathrm{~g} / \mathrm{cm}^{3}$ dari target kerapatan $0,8 \mathrm{~g} / \mathrm{cm}^{3}$. Semua papan partikel dapat dibuat tanpa ada yang mengalami delaminasi. Warna papan partikel semakin gelap dengan semakin banyaknya jumlah asam sitrat yang diberikan (Gambar 1). Hal ini diduga karena penambahan asam sitrat dan asap cair sebagai pelarut pada partikel kulit kacang tanah dapat merubah warna dari papan partikel yang dihasilkan. Hal yang sama juga 
ditemukan oleh Widyorini et al. (2014) yang meneliti papan partikel dari bambu dengan penambahan asam sitrat dan Umemura et al (2011) yang meneliti produk cetakan kayu akasia dengan penambahan asam sitrat.

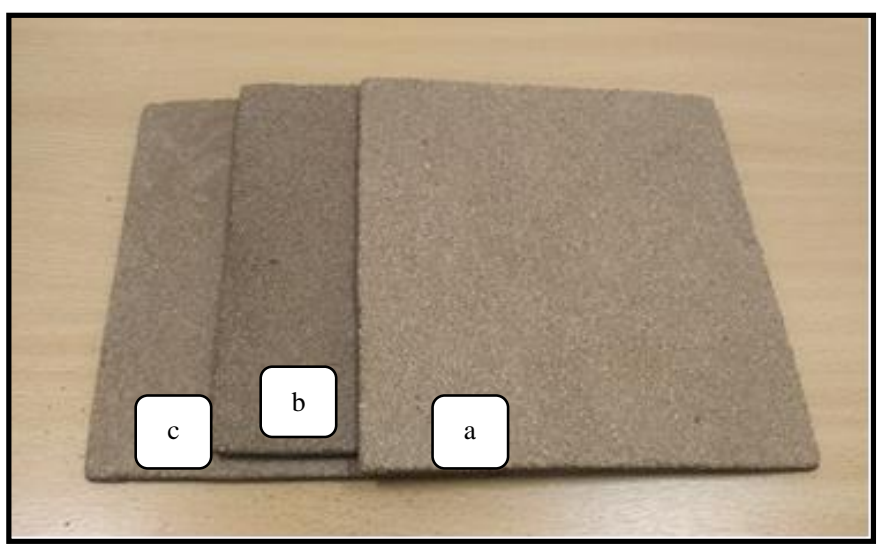

Gambar 1. Papan partikel kulit kacang tanah dengan berbagai variasi kadar perekat asam sitrat $(10 \%=a),(20 \%=b)$, dan $(30 \%=c)$

Figure 1. Particleboard made of peanut shell with variying of citric acid adhesive contents $(10 \%=a),(20 \%=b)$, dan $(30 \%=c)$

Tabel 1. Rekapitulasi nilai pengujian sifat fisika dan mekanika papan partikel Table 1. Recapitulation of test values of physical and mechanical properties of particleboard

\begin{tabular}{ccccccc}
\hline No & Sampel Perlakuan & $\begin{array}{c}\text { WA } \\
(\%)\end{array}$ & $\begin{array}{c}\text { TS } \\
(\%)\end{array}$ & $\begin{array}{c}\text { IB } \\
\left(\mathbf{k g} / \mathbf{c m}^{2}\right)\end{array}$ & $\begin{array}{c}\text { MoR } \\
\left(\mathbf{k g f} / \mathbf{c m}^{2}\right)\end{array}$ & $\begin{array}{c}\text { MoE } \\
\left(\mathbf{k g f} / \mathbf{c m}^{2}\right)\end{array}$ \\
\hline 1 & Waktu kempa 10 menit, Sitrat 10\% & 79,77 & 11,34 & 1,12 & 6,41 & $2.150,18$ \\
2 & Waktu kempa 10 menit, Sitrat 20\% & 51,86 & 7,85 & 2,36 & 11,82 & $4.386,26$ \\
3 & Waktu kempa 10 menit, Sitrat 30\% & 44,38 & 3,77 & 4,93 & 24,73 & $8.833,08$ \\
4 & Waktu kempa 15 menit, Sitrat 10\% & 67,15 & 9,85 & 1,14 & 5,36 & $2.150,15$ \\
5 & Waktu kempa 15 menit, Sitrat 20\% & 58,26 & 5,92 & 2,11 & 7,95 & $3.879,84$ \\
6 & Waktu kempa 15 menit, Sitrat 30\% & 44,99 & 3,27 & 4,68 & 26,82 & $8.909,57$ \\
\hline & Standar JIS A 5908-2003 & - & Maks. & Min. 1,5 & Min. 82 & Min 20,40x \\
\hline
\end{tabular}

Sumber: Japanese Standard Association (2003)

Tabel 2 menunjukkan bahwa faktor waktu kempa berpengaruh signifikan pada taraf uji 0,05 hanya pada parameter nilai pengembangan tebal papan partikel kulit kacang tanah. Kadar perekat asam sitrat berpengaruh signifikan pada taraf uji 0,01 pada parameter pengembangan tebal, penyerapan air, keteguhan rekat internal, modulus patah dan modulus elastisitas papan partikel. Interaksi antara waktu kempa dan kadar perekat asam sitrat hanya memberikan pengaruh signifikan pada taraf uji 0,05 hanya pada parameter nilai penyerapan air papan partikel.

Faktor waktu kempa tidak begitu banyak berpengaruh pada penelitian ini diduga karena perbedaan waktu antara 10 menit dan 15 menit masih terlalu singkat untuk dapat merubah sifat-sifat papan partikel yang terbuat dari kulit kacang tanah. Penelitian lain oleh Wahyudi et al. (2017) memberikan hasil yang berbeda dimana lama waktu pengempaan 10 dan 15 menit memberikan pengaruh yang signifikan pada sifat fisika dan mekanika papan partikel kayu mahang dengan perekat asam malat. Pengaruh variasi waktu kempa pada sifat apan partikel ini diduga dipengaruhi oleh komponen kimia bahan baku yang dibuat papan 
Jurnal Belantara [JBL] Vol. 1, No. 2, Agustus 2018 (77-88)

partikel sehingga pada masing-masing bahan baku akan menunjukkan pengaruh yang berbeda.

Tabel 2. Rekapitulasi hasil analisis varians sifat fisika dan mekanika papan partikel

Table 2. Recapitulation of results of variance analysis of physical and mechanical properties of particleboard

\begin{tabular}{cccc}
\hline \multirow{2}{*}{ Parameter } & \multicolumn{3}{c}{ Papan Partikel Kulit Kacang Tanah } \\
\cline { 2 - 4 } & Waktu Kempa & Kadar Perekat & Interaksi \\
\hline Penyerapan Air & $0,512 \mathrm{~ns}$ & $0,000^{* *}$ & $0,029^{*}$ \\
Pengembangan Tebal & $0,016^{*}$ & $0,000^{* *}$ & $0,508 \mathrm{~ns}$ \\
Modulus Patah & $0,820 \mathrm{~ns}$ & $0,005^{* *}$ & $0,812 \mathrm{~ns}$ \\
Modulus Elastisitas & $0,795 \mathrm{~ns}$ & $0,001^{* *}$ & $0,879 \mathrm{~ns}$ \\
Keteguhan rekat Internal & $0,666 \mathrm{~ns}$ & $0,006^{* *}$ & $0,906 \mathrm{~ns}$ \\
\hline Ket: ${ }^{* *}=$ signifikan taraf uji $0,01^{*}$ & $=$ signifikan taraf uji $0,05 \mathrm{~ns}=$ nilai tidak berbeda nyata
\end{tabular}

Gambar 2 menunjukkan hubungan antara pengembangan tebal dan penyerapan air papan partikel dari kulit kacang tanah pada berbagai kadar perekat asam sitrat (10\% - 30\%) dan lama waktu pengempaan 10 menit dan 15 menit. Nilai ini diperoleh setelah perendaman air pada suhu ruangan selama 24 jam. Semua papan partikel yang dihasilkan dengan penambahan asam sitrat menunjukkan kualitas yang baik dan dapat memenuhi standar JIS A 5908 (kurang dari 12\%). Sementara itu, faktor waktu kempa hanya memberikan pengaruh yang signifikan pada nilai pengembangan tebal. Semakin lama waktu pengempaan memperbaiki sifat pengembangan tebal papan partikel. Jumlah asam sitrat yang meningkat dari 10\%-30 \% menyebabkan naiknya kestabilan dimensi papan partikel. Hal ini terlihat dari nilai pengembangan tebal dan penyerapan air untuk papan partikel (10\%) adalah $11,34 \%$ dan $79,77 \%$ kemudian menjadi $3,77 \%$ dan $44,38 \%$ pada penambahan asam sitrat $30 \%$ dan waktu kempa 10 menit.
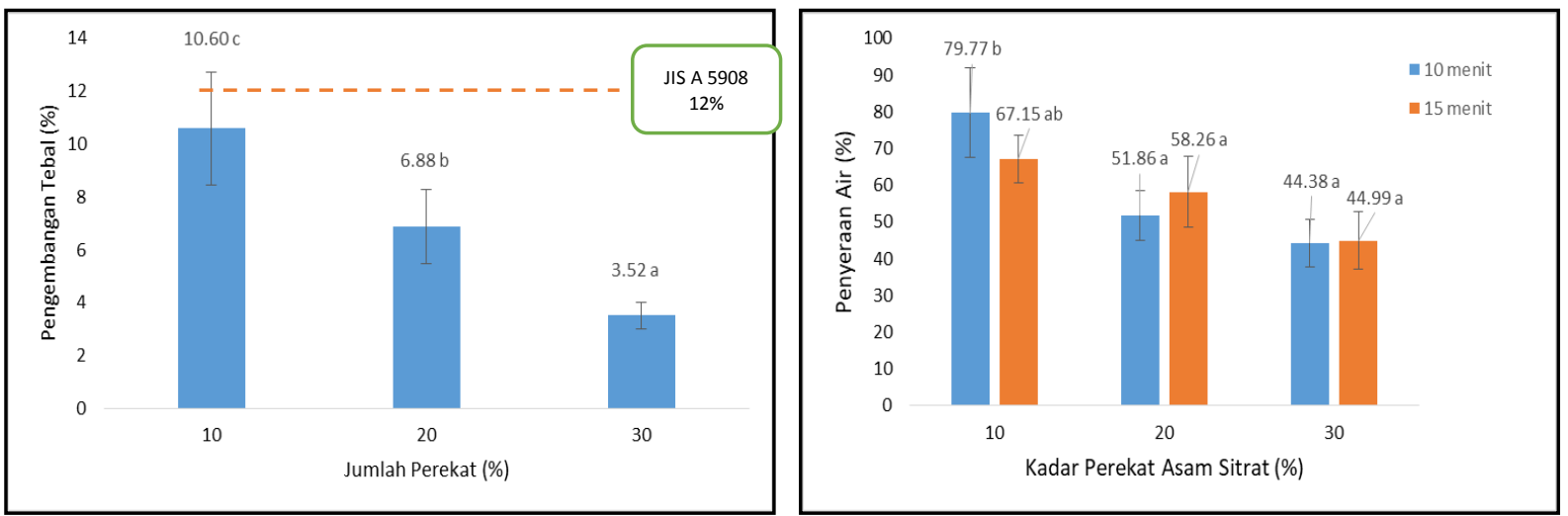

Gambar 2. Nilai pengembangan tebal dan penyerapan air papan partikel pada berbagai variasi waktu pengempaan dan kadar perekat asam sitrat

Figure 2. The value of thickness swelling and water absorption at various pressing time and citric acid adhesive contents

Penambahan asam sitrat dimaksudkan untuk meningkatkan sifat fisika papan partikel kulit kacang tanah, terutama sifat ketahanan terhadap air. Peningkatan stabilitas dimensi terlihat dengan penurunan nilai pengembangan tebal dan penyerapan air seiring dengan penambahan asam sitrat. Penambahan asam sitrat menghasilkan papan partikel 
yang memenuhi standar JIS A 5908, dimana jumlah asam sitrat 30\% dengan waktu kempa 15 menit menghasilkan nilai penyerapan air dan pengembangan tebal papan partikel kulit kacang tanah terendah yaitu sebesar 44,99\% dan 3,27\%. Peningkatan sifat kestabilan dimensi pada papan partikel kulit kacang tanah terjadi seiring meningkatnya penggunaan asam sitrat. Penelitian yang dilakukan oleh Widyorini et al. (2015) mengenai sifat fisika mekanika dan ketahanan papan partikel bambu dengan perekat asam sitrat memberikan nilai pengembangan tebal yang semakin menurun dari $20 \%$ menjadi $1 \%$ pada suhu pengempaan $200^{\circ} \mathrm{C}$ dengan bertambahnya kadar perekat asam sitrat dari $0 \%-40 \%$.

Sifat mekanika yang diamati pada penelitian ini meliputi keteguhan lengkung statis dan keteguhan rekat internal. Gambar 3 dan 4 menunjukkan sifat mekanika papan partikel kulit kacang tanah pada berbagai kadar perekat asam sitrat (10\%-30\%). Hasil analisis varian menunjukkan bahwa hanya faktor kadar perekat asam sitrat saja yang berpengatuh signifikan pada taraf uji 0,01 terhadap sifat mekanika papan partikel. Nilai modulus patah dan modulus elastisitas papan partikel kulit kacang tanah memperlihatkan peningkatan nilai dengan bertambahnya kadar perekat asam sitrat (Gambar 3), tetapi perbedaan lama waktu pengempaan tidak menyebabkan pengaruh nyata pada kedua nilai tersebut. Penambahan kadar perekat asam sitrat dari 10\%-30\% belum dapat memenuhi standar JIS A 5908 tipe 8 (modulus patah minimal $82 \mathrm{kgf} / \mathrm{cm}^{2}$ dan modulus elastisitas minimal $20,4 \times 10^{3} \mathrm{kgf} / \mathrm{cm}^{2}$ ).
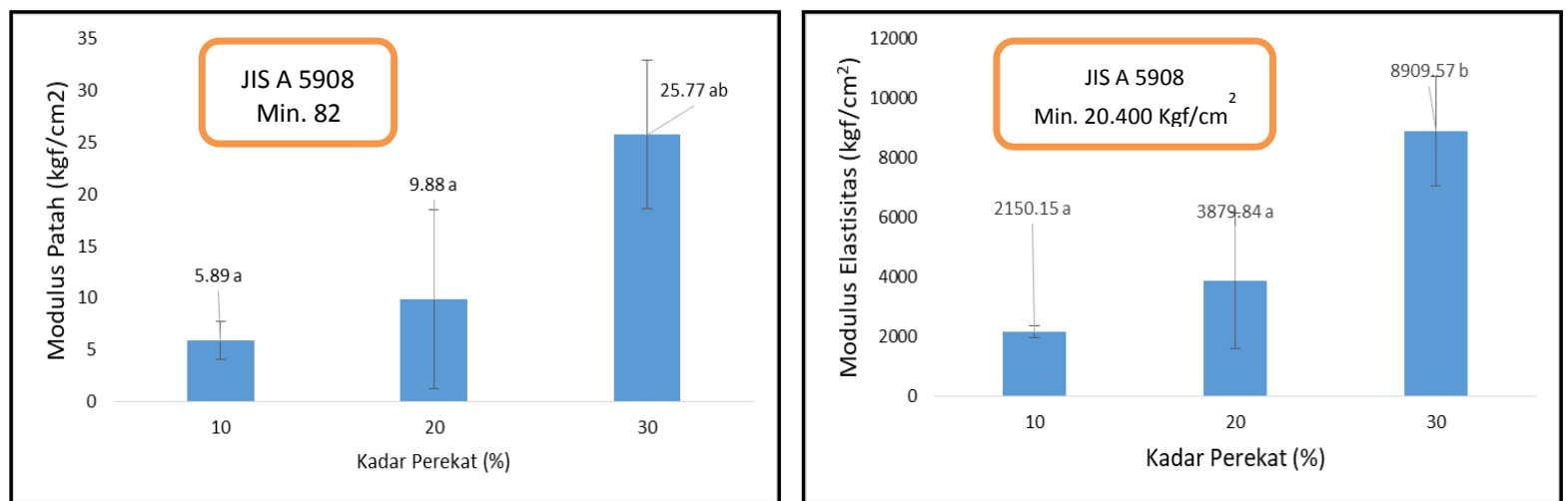

Gambar 3. Nilai modulus patah dan elastisitas papan partikel kulit kacang tanah pada berbagai variasi kadar perekat asam sitrat

Figure 3. The value of modulus of rufture and modulus of elasticity of particleboard made of peanut shells at various citric acid adhesive contents

Nilai rata-rata modulus patah dan modulus elastisitas terendah didapatkan pada penambahan asam sitrat $10 \%$ dengan waktu kempa 15 menit yaitu sebesar $5,36 \mathrm{kgf} / \mathrm{cm}^{2}$ dan $2.150,15 \mathrm{kgf} / \mathrm{cm}^{2}$, sedangkan nilai modulus patah dan modulus elastisitas tertinggi diperoleh dengan penambahan asam sitrat sebesar 30\% dengan waktu kempa 15 menit yaitu sebesar $26,82 \mathrm{kgf} / \mathrm{cm}^{2}$ dan $8.909,57 \mathrm{kgf} / \mathrm{cm}^{2}$. Semua nilai modulus patah dan modulus elastisitas yang dihasilkan pada penelitian ini belum memenuhi standar JIS A 5908 tipe 8 yaitu sebesar $82 \mathrm{kgf} / \mathrm{cm}^{2}$ untuk modulus patah dan $20,4 \times 10^{3} \mathrm{kgf} / \mathrm{cm}^{2}$ untuk modulus elastisitas. Hasil berbeda dihasilkan oleh penelitian Umemura et al. (2012), dimana penggunaan asam sitrat $20 \%$ pada produk molding menghasilkan sifat mekanika yang optimal. Hal ini memperlihatkan bahwa sifat bahan baku juga turut mempengaruhi keberhasilan ikatan dengan asam sitrat. 


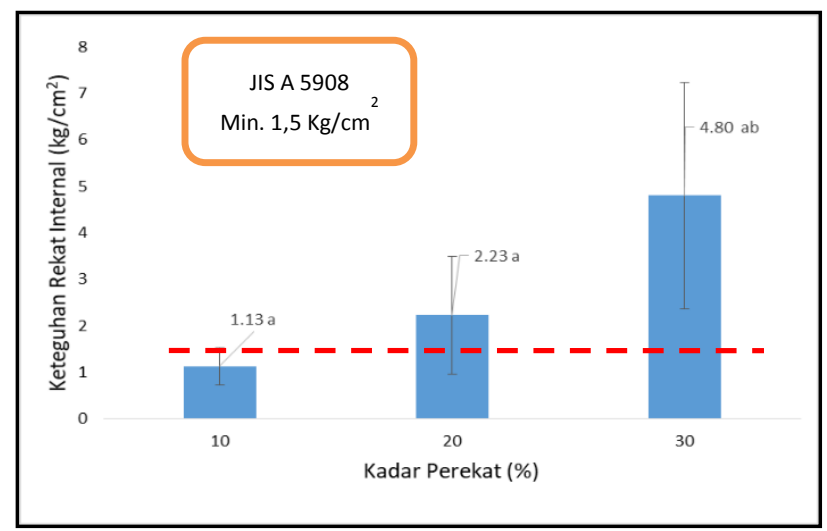

Gambar 4. Nilai kekuatan rekat internal papan partikel kulit kacang tanah pada berbagai variasi kadar perekat asam sitrat

Figure 4. The value of the internal bonding of particleboard made of peanut shells at various citric acid adhesive contents

Gambar 4 menunjukkan nilai kekuatan rekat internal papan partikel kulit kacang tanah pada berbagai kadar perekat asam sitrat (10\%-30\%). Nilai kekuatan rekat internal papan partikel dari kulit kacang tanah memperlihatkan peningkatan dengan bertambahnya jumlah asam sitrat sampai $30 \%$. Nilai keteguhan rekat internal ini tidak seluruhnya memenuhi Standar JIS A 5908-2003 (Anonim, 2003) yaitu minimal $1,5 \mathrm{~kg} / \mathrm{cm}^{2}$ yaitu pada papan partikel dengan kadar perekat asam sitrat 10\%, sedangkan penambahan kadar perekat dari $20 \%$ $30 \%$ dapat memberikan nilai yang memenuhi standar. Perbedaan waktu pengempaan tidak menyebabkan pengaruh nyata pada nilai kekuatan rekat internal, namun terdapat kecendrungan dimana semakin lama waktu kempa menyebabkan penurunan nilai tersebut. $\mathrm{Hal}$ ini kemungkinan disebabkan oleh waktu pengempaan yang lebih lama menyebabkan degradasi komponen kimia yang berlebihan dan menyebabkan penurunan kualitas papan (Suzuki et al., 1998). Peneitian oleh Widyorini et al. (2015) menunjukkan bahwa rata-rata keteguhan rekat internal papan partikel bambu menurun dengan bertambahnya suhu pengempaan dari $200^{\circ} \mathrm{C}$ sampai $220^{\circ} \mathrm{C}$.

Nilai keteguhan rekat internal pada penelitian ini berkisar antara $1,11 \mathrm{~kg} / \mathrm{cm}^{2}-4,93$ $\mathrm{kg} / \mathrm{cm}^{2}$. Penambahan kadar perekat asam sitrat akan meningkatan nilai keteguhan rekat internal. Peningkatan pemakaian kadar perekat mengakibatkan permukaan partikel yang terlaburi perekat akan makin luas sehingga kontak antar partikel yang terjadi akan lebih besar dan rakitan partikel makin mantap. Pembuatan papan partikel dengan penambahan asam sitrat $10 \%$ tidak ada yang memenuhi standar. Pada Gambar 4 menunjukkan bahwa penambahan asam sitrat sampai $20 \%$, kekuatan rekat internal papan partikel kulit kacang tanah naik 2 (dua) kali baik pada waktu kempa 10 menit maupun 15 menit. Sementara itu, penambahan asam sitrat sampai $30 \%$ masih mampu meningkatkan nilai kekuatan rekat internal sebesar 2 (dua) kali dibanding nilai kekuatan rekat internal dengan penambahan asam sitrat 20\%. Menurut Umemura et al. (2012), rata-rata keteguhan rekat internal papan partikel dari softwood yang diberi tambahan asam sitrat hingga $30 \%$ adalah $1,61 \mathrm{MPa}$ (lima kali lebih tinggi dibanding $5 \%$ ).

\section{Sifat Ketahanan Papan Partikel Terhadap Serangan Rayap Kayu Kering}

Sifat ketahanan rayap yang diamati pada penelitian ini meliputi mortalitas rayap dan pengurangan berat papan partikel. Nilai Mortalitas rayap kayu kering pada papan partikel dari kulit kacang tanah diamati mulai minggu ke-1 hingga minggu ke-4. Pengamatan yang dilakukan pada minggu ke-4 menunjukkan nilai mortalitas rayap berkisar antara 32,67 $45,33 \%$ dengan nilai pengurangan berat berkisar antara 1,08\% sampai $2,13 \%$ seperti terlihat 
pada Tabel 3. Tabel 4 menunjukkan bahwa hanya faktor kadar perekat saja yang berpengaruh pada parameter pengurangan berat papan partikel setelah diserangkan rayap kayu kering. Sementara itu, faktor waktu kempa maupun interaksi antara waktu kempa dan kadar perekat asam sitrat tidak memberikan pengaruh signifikan pada parameter nilai mortalitas rayap dan kehilangan berat papan partikel.

Tabel 3. Nilai mortalitas rayap dan kehilangan berat papan partikel Table 3. The value of termite mortality and weight loss of particleboard

\begin{tabular}{cccc}
\hline No & Sampel Perlakuan & Mortalitas Rayap (\%) & Pengurangan Berat (\%) \\
\hline 1 & Waktu kempa 10 menit, Sitrat 10\% & 34,00 & 2,13 \\
2 & Waktu kempa 10 menit, Sitrat 20\% & 34,00 & 1,90 \\
3 & Waktu kempa 10 menit, Sitrat 30\% & 38,67 & 1,08 \\
4 & Waktu kempa 15 menit, Sitrat 10\% & 30,67 & 2,12 \\
5 & Waktu kempa 15 menit, Sitrat 20\% & 45,33 & 1,98 \\
6 & Waktu kempa 15 menit, Sitrat 30\% & 32,67 & 1,20 \\
\hline
\end{tabular}

Tabel 4. Nilai analisis varians mortalitas rayap dan kehilangan berat papan partikel

Table 4. Value of variance analysis of termite mortality and weight loss of particleboard

\begin{tabular}{cccc}
\hline \multirow{2}{*}{ Parameter } & \multicolumn{3}{c}{ Papan Partikel Kulit Kacang Tanah } \\
\cline { 2 - 2 } & Waktu Kempa & Kadar Perekat & Interaksi \\
\hline Mortalitas Rayap & $0,883 \mathrm{~ns}$ & $0,438 \mathrm{~ns}$ & $0,264 \mathrm{~ns}$ \\
Pengurangan Berat & $0,752 \mathrm{~ns}$ & $0,005^{\star *}$ & $0,970 \mathrm{~ns}$ \\
\hline
\end{tabular}

Ket $:{ }^{* *}=$ signifikan taraf uji 0,01 dan ns $=$ nilai tidak berbeda nyata

Pada penelitian ini, penggunaan asap cair sebagai pelarut pengganti aquades dalam membuat larutan perekat asam sitrat tidak memberikan dampak yang signifikan bagi peningkatan ketahanan papan partikel dari serangan rayap kayu kering terutama nilai mortalitasnya. Perbandingan konsentrasi perekat asam sitrat dan pelarut dalam penelitian ini adalah $60 \%$ asam sitrat : $40 \%$ pelarut asap cair. Pada penelitian ini, banyaknya asap cair sebagai pelarut yang dipakai adalah 23,33 gram untuk kadar perekat asam sitrat 10\%, 46,66 gram untuk kadar perekat asam sitrat $20 \%$ dan sebanyak 69,99 gram untuk kadar perekat asam sitrat $30 \%$. Asap cair pada penelitian ini diperoleh dari pirolisis tempurung kelapa. Komposisi kimia tempurung kelapa meliputi kadar fenol sebesar 5,13\%, karbonil sebesar $13,28 \%$ dan asam sebesar 11,39\% (Darmadji, 2002). Yefrida et al. (2008) dalam penelitiannya menyatakan bahwa asap cair dari tempurung kelapa memiliki $\mathrm{pH} 3,21$ yang berarti memiliki sifat asam dan sifat antibakteri yang sangat baik. Waktu pengumpanan yang berlangsung selama 4 minggu pada penelitian ini diduga belum dapat memberikan nilai mortalitas rayap yang maksimal. Kecendrungan yang diamati pada penelitian ini yaitu rayap kayu kering tidak memakan contoh uji papan partikel yang diberikan yang ditandai dengan kecilnya nilai pengurangan berat contoh uji papan partikel. Penambahan kombinasi antara asap cair dan perekat asam sitrat diguda menjadi penolak (antibakterial) bagi rayap kayu kering untuk memakan atau menyerang contoh uji.

Hasil penelitian Widyorini et al. (2015) mengenai sifat ketahanan papan partikel bambu dengan perekat asam sitrat $0-40 \%$ yang diserangkan pada rayap kayu kering selama 6 minggu menunjukkan nilai yang lebih baik. Penelitian lain oleh Indrayani et al., 2010 juga menunjukkan hasil bahwa mortalitas rayap meningkat dengan naiknya konsentrasi asap cair dari $1 \%-4 \%$ serta tingginya suhu pirolisis $450^{\circ} \mathrm{C}$ dengan nilai mortalitas rayap mencapai $100 \%$ pada lama waktu pengumpanan selama 12 minggu. Pengumpanan selama 6 dan 12 minggu pada kedua penelitian diatas diduga menjadi waktu yang optimal bagi kematian 
rayap karena tidak melakukan aktivitas memakan sehingga banyak yang mengalami kematian pada akhir periode pengumpanan selain juga oleh pengaruh asam yang terdapat pada asam sitrat maupun asap cair.

Data hasil penelitian seperti yang ditunjukkan pada Gambar 6 menunjukkan kecenderungan pengurangan berat papan partikel dengan penambahan asam sitrat. Penambahan asam sitrat 30\% dengan waktu kempa 10 menit menghasilkan pengurangan berat terendah yaitu $1,08 \%$, sedangkan tertinggi sebesar $2,13 \%$ pada waktu kempa yang sama dengan jumlah perekat asam sitrat 10\%. Penelitian Widyorini et al. (2015) menunjukkan bahwa pengurangan berat setelah 6 minggu dari papan partikel bambu dengan perekat asam sitrat berkisar antara 0,5-1,4\% tergantung pada konsentrasi asam sitrat yang diberikan yaitu dari $0-40 \%$ pada suhu $200-220^{\circ} \mathrm{C}$. Dibandingkan dengan hasil tersebut, papan partikel dari kulit kacang tanah dengan perekat asam sitrat dan pelarut asap cair ini memperlihatkan ketahanan terhadap serangan rayap kayu kering yang lebih rendah. Hal ini diduga karena penggunaan suhu pengempaan dan kadar perekat asam sitrat yang berbeda.

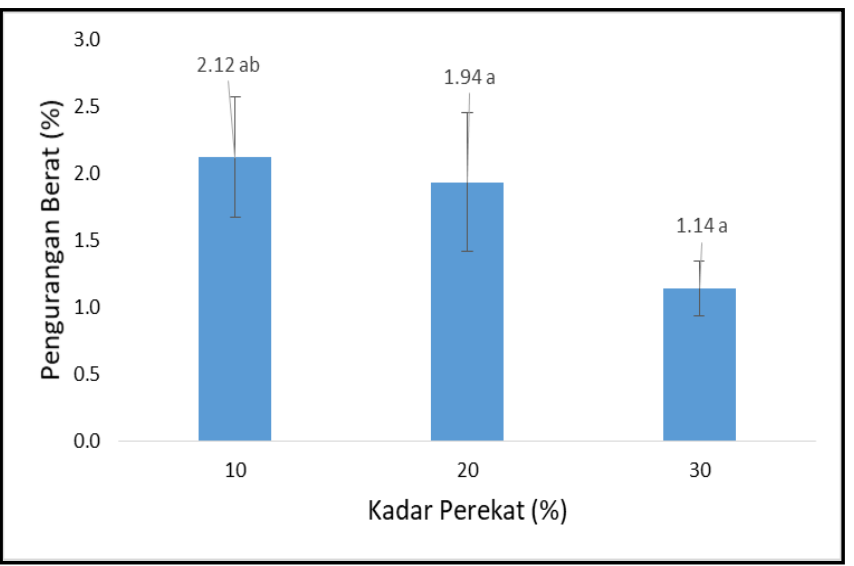

Gambar 5. Nilai pengurangan berat papan partikel kulit kacang tanah pada berbagai variasi kadar perekat asam sitrat

Figure 5. The values of weight loss of particleboard made of peanut shells at various citric acid adhesive contents

\section{Kesimpulan}

Peningkatan sifat fisika dan mekanika papan partikel kulit kacang tanah terlihat dengan semakin banyaknya asam sitrat yang ditambahkan. Karakteristik papan partikel dari kulit kacang tanah terbaik diperoleh pada interaksi perlakuan waktu kempa 15 menit dan kadar perekat asam sitrat sebesar $30 \%$ dengan pengembangan tebal sebesar $3,276 \%$, nilai penyerapan air sebesar 44,991\%, nilai keteguhan rekat internal sebesar $4,679 \mathrm{~kg} / \mathrm{cm}^{2}$, nilai modulus patah sebesar $26,822 \mathrm{kgf} / \mathrm{cm}^{2}$ dan nilai modulus elastisitas sebesar 8.986,058 $\mathrm{kgf} / \mathrm{cm}^{2}$. Penambahan asam sitrat dengan pelarut asap cair pada papan partikel dari kulit kacang tanah dapat menghasilkan papan dengan ketahanan terhadap rayap kayu kering yang baik dengan nilai pengurangan berat papan partikel berkisar antara $1,083-2,125 \%$. 


\section{Daftar Pustaka}

Anonim. 2015. Manfaat dan Potensi Kacang Tanah dalam Mendukung Pertanian BioIndustri. Balai Penelitian Tanaman Aneka Kacang dan Umbi. http://www. balitkabi.litbang.pertanian.go.id. Diakses Februari 2017.

Bratzler, L. J., M. E. Spooner, J. B. Weathspoon and J. A. Maxey. 1969. Smoke Flavor as Related to Phenol, Carbonyl and Acid Content of Bologna. J. Food Sci. 34: 146.

Japanese Standard Association. 2003. Japanese Industrial Standard for Particleboard A 5908. Japanese Standard Association. Tokyo.

Japanese Industrial Standard. 2004. JIS K 1571 Test Methods for Determining the Effectiveness of Wood Preservatives and Their Performance Requirements. Japanese Standard Association. Tokyo.

Darmadji, P. 2002. Optimalisasi Pemurnian Asap Cair dengan Metoda Redistilasi. Jurnal Teknologi dan Industri Pangan. Volume 13(3), 267-271.

Departemen Pertanian Republik Indonesia. 2008. Permasalahan Kacang Tanah di Lahan Kering. http://www.deptan.go.id. Diakses Februari 2017.

Indrayani, Y. H.A. Oramahi, dan Nurhaida. 2010. Evaluation of Liquid Smoke as BioPesticide to Control Subterranean Termites Cryptotermes sp. Jurnal Ketawang Fakultas Kehutanan Universitas Tanjungpura Pontianak. Hal 87-96.

Laemsak N \& Okuma M. 2000. Development of boards made from oil palm frond II: Properties of binderless boards from steam-exploded fibers of oil palm frond. Journal of Wood Science 46, 322-326.

Maga, J. A. 1988. Smoke in food Processing. CRC Press. Florida.

Okuda N \& Sato M. 2006. Water resistance properties of kenaf core binderless boards. Journal of Wood Science 52, 422-428.

Suzuki S, Shintani H, Park SY, Saito K, Laemsak N, Okuma M, \& liyama K. 1998. Preparation of binderless boards from steam exploded pulps of oil palm (Elaeis guneensis Jaxq) fronds and structural characteristics of lignin and wall polysaccharides in steam exploded pulps to be discussed or self-bonding. Holzforschung 52, 417-426.

Umemura K, Ueda T, Munawar SS, \& Kawai S. 2011. Application of citric acid as natural adhesive for wood. Journal of Applied Polymer Science 123, 1991-1996

Umemura K, Ueda T, \& Kawai S. 2012. Characterization of wood-based molding bonded with citric acid. Journal of Wood Science 58, 38-45.

Van Dam J. E. G., M. J. A. Van den Oever, E. R. P. Keijsers, J. C. Van der Putten, C. Anayron, F. Josol, dan A. Peralta. 2004. Process for Production of High Density/ High Performance Binderless Boards from Whole Coconut Husk. Indust.Crops Prod 19: 207-216.

Velazquez J.A., F. Ferrando, dan J. Salvado. 2002. Binderless Fiberboard from Steam Exploded Miscanthus Sinensis: The Effect of a Grinding Process. Holz Roh- Werkstoff 60: 297-302.

Wahyudi A, Prayitno T.A., Widyorini R., Sutapa J.P.G. 2017. Pengaruh Suhu dan Waktu Pengempaan Terhadap Sifat Papan Serat Kerapatan Sedang dari Kayu Mahang Dengan Perekat Asam Malat. Jurnal Penelitian Kehutanan Sumatrana. Volume1 No. 1, 55-61.

Walther T, Kartal SN, Hwang WJ, Umemura K, \& Kawai S. 2007. Strength, decay, and termite resistance of oriented kenaf fiberboards. Journal of Wood Science 53, 481486.

Widyorini R, Higashihara $T$, Xu J, Watanabe T, \& Kawai S. 2005. Self-bonding characteristics of binderless kenaf core composites. Wood and Science Technology 
39, 651-662.

Widyorini R, Yudha AP, Adifandi Y, Umemura K, \& Kawai S. 2013. Characteristics of bamboo particleboard bonded with citric acid. Wood Research Journal 4(1), 31-35.

Widyorini R, Yudha AP, Isnan R, Awaludin A, Prayitno TA, Ngadianto A, \& Umemura K. 2014. Improving the physico-mechanical properties of eco-friendly composite made from bamboo. Advanced Material Research 896, 562-565.

Widyorini R., AP. Yudha, G. Lukmandaru, dan TA. Prayitno. 2015. Sifat Fisika Mekanika dan Ketaahanan Papan Partikel Bambu dengan Perekat Asam Sitrat Terhadap Serangan Rayap Kayu Kering. Jurnal Ilmu Kehutanan: Volume 9 No.1, 12-22.

Xu J, Han G, \& Kawai S. 2003. Development of binderless particleboard from kenaf core using steam-injection pressing. Journal of Wood Science 49, 327-332.

Yefrida, Y. K. Putri, R. Silvianti, N. Lucia, Refilda, Indrawati. 2008. Pembuatan Asap Cair dari Limbah Kayu Suren (Toona sureni), Sabut Kelapa dan Tempurung Kelapa (Cocos nucifera Linn). Jurnal Riset Kimia. Volume 1(2), 187-191. 